\title{
CONSIDERING THE STATE OF THE UKRAINIAN ECONOMY IN THE ENTERPRISES FINANCIAL SUSTAINABILITY MODELING
}

\author{
Leonid Debunov ${ }^{1}$, Aleksandr Yakovenko
}

\begin{abstract}
Construction of a model for predicting the bankruptcy of the enterprise is an urgent and popular task. Using this model will provide an opportunity to make quick and accurate assessment of financial sustainability, predict possible bankruptcy advance and take the necessary action to avoid it. Obviously, bankruptcy can occur both under the influence of internal factors (in particular, financial management errors) and when the economic environment changes. The inclusion of all possible environmental factors influencing into the model is a difficult task and causes an overload of such a model with a large number of input signals. A more realistic option is to build a model using internal financial indicators only, but under a relatively constant external environment. The subject of the study described in the article is the general homogeneity of the Ukrainian economy over time in the context of the possibility of using companies' reports for these periods to build a neural network model of financial sustainability of enterprises using only internal financial indicators. To separate stable periods from unstable ones, a review of the dynamics of macroeconomic indicators of Ukraine for the period 2010-2019 is used. Graphical analysis of the dynamics of macroeconomic indicators is used as a methodology. The purpose of this study is to identify periods of Ukraine's economy, the conditions of which are quite stable to take reports of enterprises of these periods for a dataset formation. The article considers the dynamics of the following indicators of Ukraine's economy: gross domestic product, hryvnia exchange rate, employment, consumer price index, total net profit (loss) of enterprises by size of enterprises, levels of profitability of operating activities, foreign trade indicators by geographical areas (imports and exports of goods and services) etc. The study pays special attention to the economic crisis of 2014-2015 and to changes in the economic environment, which distinguish the conditions before and after the crisis. The main conclusions of the article are the recognition of the existence of crisis phenomena in the period 2014-2015 and the recognition of the difference between the post-crisis period and the pre-crisis period. In order to build an up-to-date model of financial sustainability, it is recommended to use report data for periods not earlier than 2016.
\end{abstract}

Key words: financial sustainability, bankruptcy, economic crisis, model, mac-roeconomics, analysis.

JEL Classification: E37, E20, G33

\section{Introduction}

The financial sustainability of the enterprise may be broken both by the influence of internal factors and by changes in the external economic environment. Thus, in modeling financial sustainability should be chosen one of the following approaches: a) include in the model both internal and external factors; $b$ ) to include in the model only internal indicators, but under the condition of relative invariability of the external economic environment.

Creating a model that would include external indicators is an ambitious and promising task.

Corresponding author:

${ }^{1}$ Oles Honchar Dnipro National University, Ukraine.

E-mail: debunovleonid@gmail.com

ORCID: https://orcid.org/0000-0001-9388-5845

${ }^{2}$ Oles Honchar Dnipro National University, Ukraine.

E-mail: yakovenkoA@i.ua

ORCID: https://orcid.org/0000-0003-1315-6322

ResearcherID: D-2480-2016
However, first, it requires a separate large-scale study to identify such factors and present them in the form of indicators in an acceptable for modeling form, secondly, leads to an increase of the total number of factors in the model, that is undesirable.

A more realistic option is to build a model that will include only internal factors. We must understand that such a model will be able to maintain its adequacy only in economic conditions that will not contain significant changes over time. It cannot be said that a model built for the conditions of one country retains its accuracy when applied to enterprises in another 
country. Similarly, we cannot be sure that a oncebuilt model will retain its predictive properties for decades. That is, the data of enterprises that use the model to provide an assessment should relate to the same economic conditions as the data used to build and test it.

Thus, when constructing such models, special attention should be paid to the time period of the data selected for the sample of observations that will be used in creating the model. When creating a dataset, it is necessary to avoid reports of those years that belong to periods of economic crisis. Obviously, during the economic crisis, the risk of bankruptcy of enterprises increases under the influence of external factors. In this case, the company may have approximately the same values of internal financial indicators both during the crisis and outside it, but the risk of bankruptcy during the crisis will be higher. Thus, the inclusion of observations of crisis years in the dataset can lead to erroneous assessment of the impact of the values of certain internal factors, and therefore to obtain an inadequate model. In addition, the formation of a dataset should take into consideration possible structural changes and significant shifts in the national economy. If in a short period the economic situation undergoes significant changes, in the context of financial sustainability modeling, this should be perceived as the appearance of a new economic environment. Therefore, the model created for the conditions of the old environment cannot be used for enterprises in the new conditions. There are many reasons for this: changes in the structure of costs, changes in the amount of required reserves, changes in the ability to obtain credit funds, changes in approaches to foreign exchange transactions, etc.

Thus, before creating a dataset to build a model of financial stability of enter-prises, which includes only internal factors, we must determine what time of data is acceptable to solve this task.

The authors of this study reviewed existing interpretations of the concept of "financial sustainability" (Debunov \& Yakovenko, 2019), formed a dataset of reports of Ukrainian companies and bankruptcy decisions (Debunov \& Yakovenko, 2019) and built a neural network that classifies Ukrainian companies as financially stable and potential bankrupt (Debunov, 2019). This publication focuses in more detail on the selection of the period which reports may be included to the dataset for model creation.

As mentioned above, over time, the model may lose its accuracy, so the best years to build are the least distant from today.

The purpose of this study is to identify periods of Ukraine's economy, the conditions of which are quite stable to take reports of enterprises of these periods for a dataset formation. The following questions should be answered: 1) Can we consider that 2014 is the year of economic crisis beginning? 2) What time period is covered by the economic crisis? 3) Are there any changes in the economic conjuncture between the precrisis and post-crisis periods?

\section{Gross domestic product and exchange rate}

Consider the indicators of the Ukrainian economy for the period 2010-2019. First of all, in our opinion, special attention should be paid to the period beginning in 2014, as it is known that the national economy in these years has been influenced by political factors and there has been an active phase of hostilities.

Figure 1 shows the gradual growth of Ukraine's GDP in monetary terms. However, in 2014-2015 we see a rapid growth of the GDP deflator index compared to the previous year, along with a decline in the index of the physical volume of GDP compared to the previous year. Thus, the growth of GDP in monetary terms is due to rising prices for manufactured products. At the same time, in physical terms, we see a decline in production. The graph shows a relatively stable ratio of indices until 2013 inclusive. Since 2016, we have seen the formation of a new ratio of indices, which differs from the ratio of the pre-crisis period and is quite stable. We should note that the maximum increase in prices and decline in physical production occurred in 2015. Already in 2016, we see an increase in the physical volume of GDP and a decrease in the growth rate of prices for the product.

Figure 2 shows a sharp decline in the average annual hryvnia exchange rate in the foreign exchange market. It should be noted that the devaluation of the Ukrainian national currency began in 2014. Since 2016, the rate of hryvnia depreciation had been significantly reduced, which gives reason to believe that the next years were stable.

\section{Distribution of enterprises by size}

Figure 3 shows a significant reduction in the number of large enterprises, which began in 2013 and stopped in 2016 (from 659 units to 383 units, i.e. a reduction of $41.9 \%)$. The decline in the number of medium-sized enterprises is most pronounced in 2014, and in 2017 growth begins. The mass closure of enterprises in 2014-2015 can be considered another manifestation of the crisis. From the point of view of modeling the financial stability of enterprises, it should be noted that the closure of enterprises in such large numbers indicates an increase in the complexity of doing business during this period, which is external factor for businesses. Thus, the probability of bankruptcy in these years under the influence of external factors was higher than usual (non-crisis periods). 
Vol. 1, No. 4, 2020

Three Seas ECONOMic Journal

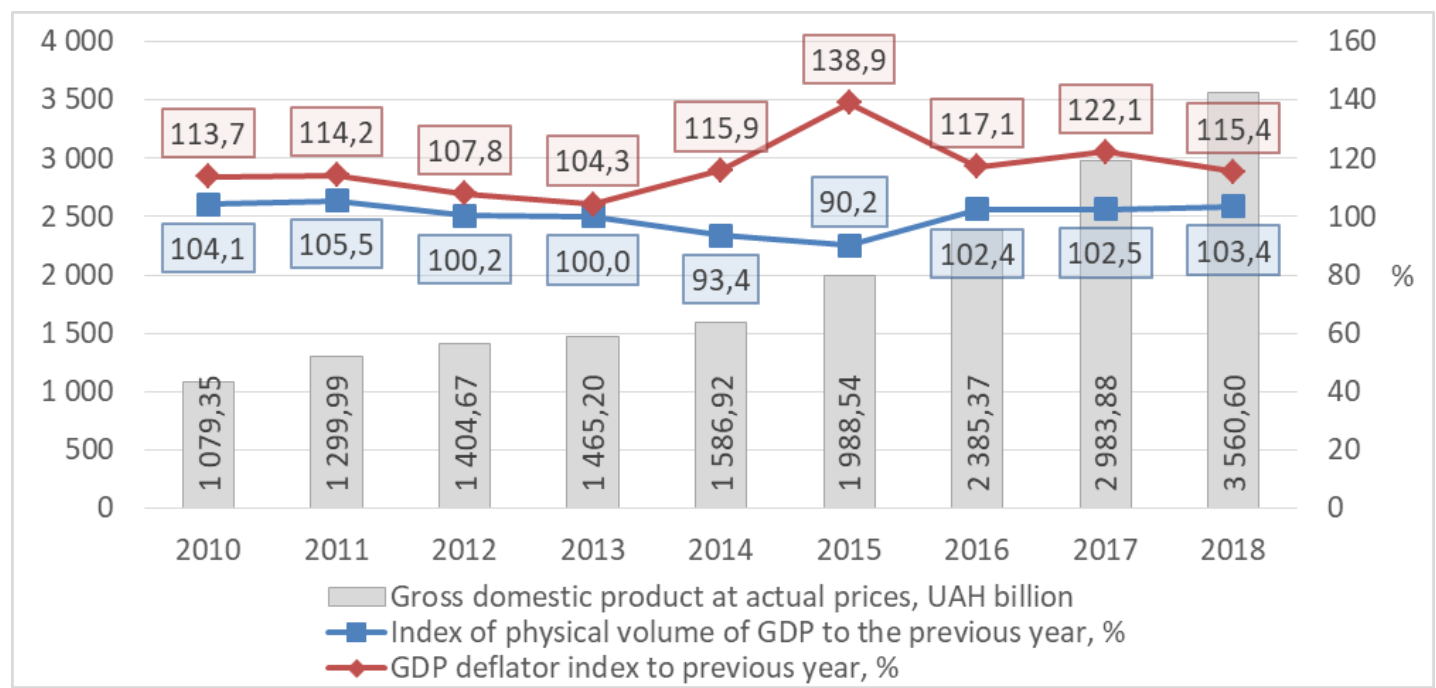

Figure 1. Dynamics factors of the volume of gross domestic product of Ukraine

Source: (Derzhavna sluzhba statystyky Ukrainy, 2021)1

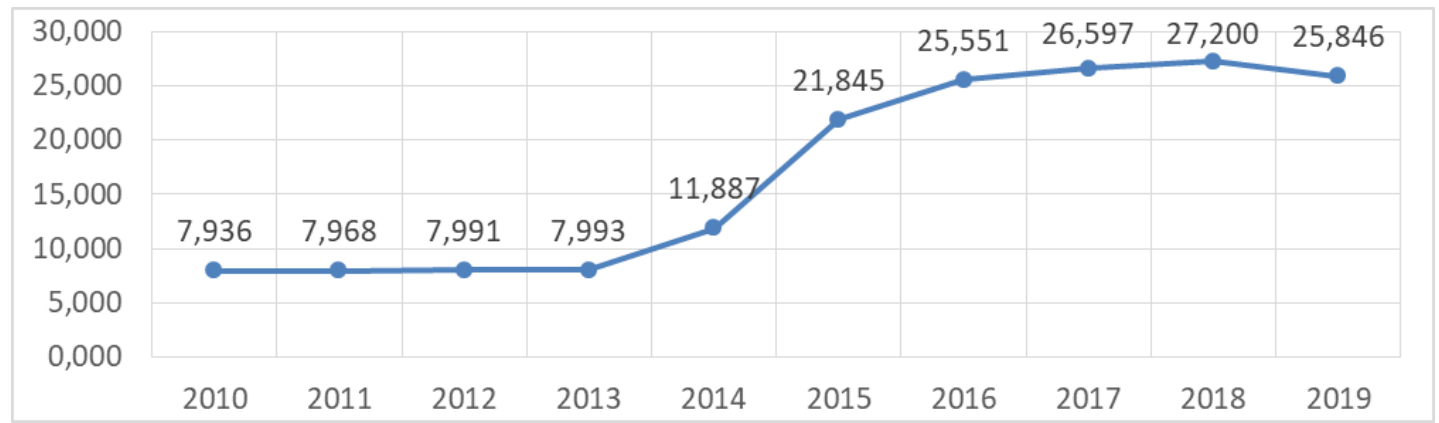

Figure 2. Official exchange rate of hryvnia to USD (average for the period)

Source: (Natsionalnyi bank Ukrainy, 2021)

Since 2014, there has been an increase in the share of products (goods and services) sold by small enterprises among all products sold in monetary terms (Figure 4). In addition, we see an increase in the share of sales of medium-sized enterprises and a decrease in the share of large ones. The described observations emphasize the tendency to reduce the role of large enterprises in aggregate production. This, in turn, supports the hypothesis of a difference in economic conditions before and after the crisis.

\section{Use of labor resources}

In Figure 5 and Figure 6 we see a sharp deterioration in the labor market, falling parts of the employed population and real wages. Undoubtedly, the graphs show the existence of a socio-economic crisis in 2014-2015. Such phenomena may be due to a sharp drop in demand for labor, a sharp rise in prices, along with the unwillingness of employers to raise wages at the same pace. We note that in 2015 the part of the employed population stops falling, and in 2016 growth of real wages returns to rates of the pre-crisis period.

Figure 7 shows the changes in the structure of employment by size of enterprises. In this graph, we draw attention to the fact that by 2013 the share of labor in-volved in large enterprises grew and exceeded the share for small enterprises. Starting from 2014, we see a change in the trend - a gradual reduction in the share of employees employed at large enterprises, from $32.2 \%$ in 2013 to $26.4 \%$ in 2018 . In addition, since 2016 , the share of labor employed in small enterprises exceeds the share of large ones. Note that the share for small enterprises is almost unchanged (fluctuates around $26.7 \%$ ), and the decrease in the share for large enterprises since 2014 is replaced by an increase in the share of employees working in medium-sized enterprises (from $40.7 \%$ in 2013 to $46.1 \%$ in 2018). These trends indicate in favor of the assertion of the difference between the economic situation of pre-crisis

\footnotetext{
${ }^{1}$ According to the methodology of the SNA 2008. In accordance with the Methodological provisions of the updated version of the system of national accounts in 2008 (order of the State Statistics Service of Ukraine dated 17.12.2013 № 398). Excluding the temporarily occupied territory of the Autonomous Republic of Crimea, the city of Sevastopol and since 2014 - also without part of the temporarily occupied territories in Donetsk and Luhansk regions
} 

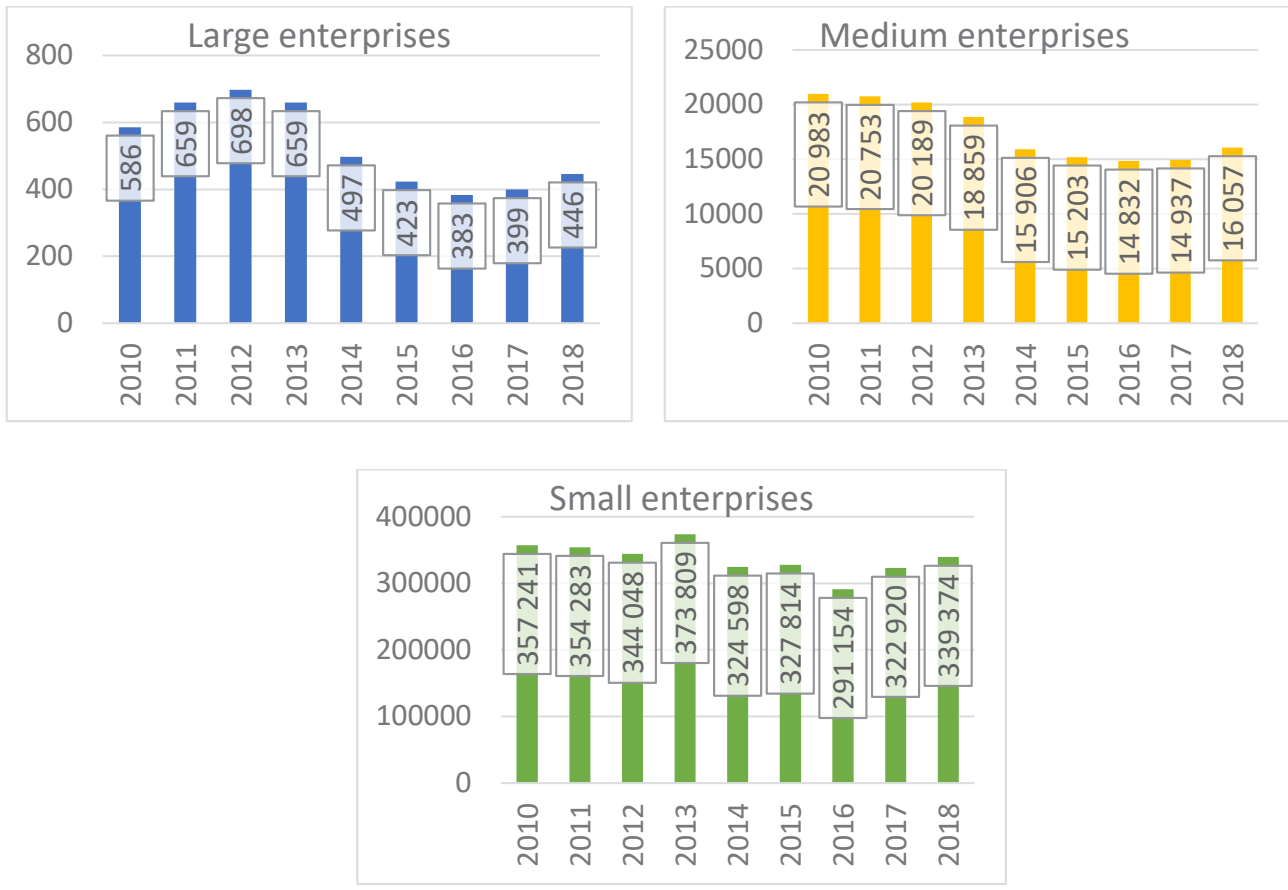

Figure 3. Number of business entities by size

Source: (Derzhavna sluzhba statystyky Ukrainy, 2021) ${ }^{2}$

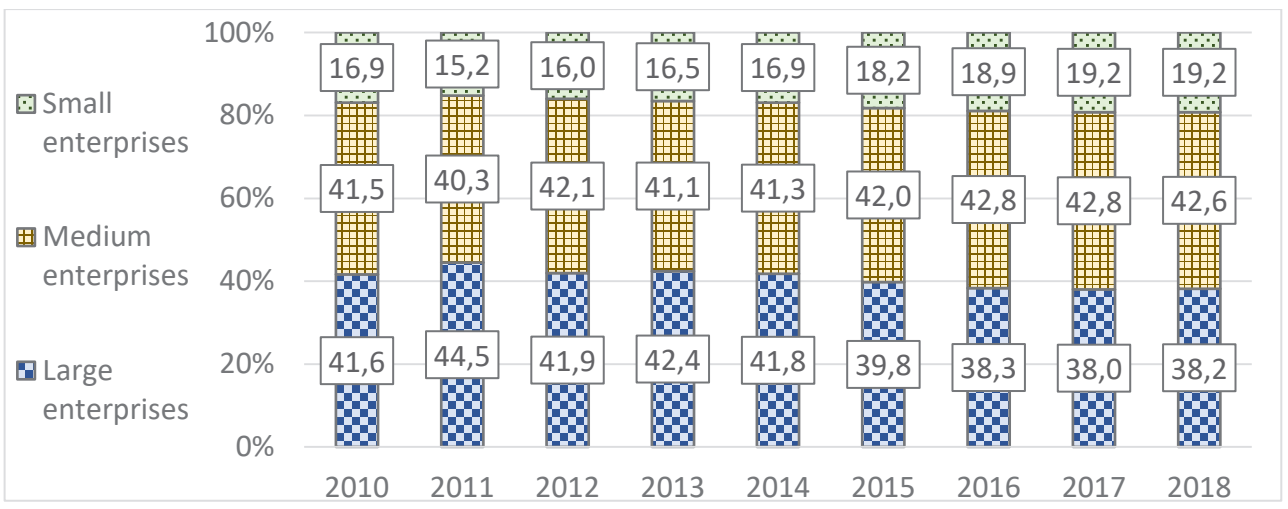

Figure 4. Distribution of the total amount of sold products (goods, services) by size of en-terprises

Source: (Derzhavna sluzhba statystyky Ukrainy, 2021) ${ }^{3}$

and post-crisis periods, as for one reason or another large enterprises as a whole show a decrease in demand for labor, which can be considered an indicator of deteriorating position of this group compared to medium and small enterprises.

According to Figure 8, there was a stable proportion of the distribution of total wages between enterprises segmented by size until 2013. The largest amount of income in the total received employees of large enterprises. In 2014, the share of wages of large enterprises began to decrease and the share of medium- sized enterprises increased. Since 2015, the largest amount of total wages was paid by a group of mediumsized enterprises $(42.9 \%$ of the total wages in the country were paid by medium-sized enterprises against $41.2 \%$ paid by large ones). The phenomena described in Figure 6 and Figure 7 indicate some changes in the economic environment of the country and should be characterized as an increase in labor demand from medium-sized enterprises combined with a weakening from large ones. We note that the time period of the beginning of these changes is 2014 .

\footnotetext{
${ }^{2}$ The data are given without taking into account the results of banks, budgetary institutions, the temporarily occupied territory of the Autonomous Republic of Crimea, the city of Sevastopol and part of the anti-terrorist operation zone.

${ }^{3}$ The data are given without taking into account the results of banks and budgetary institutions, for 2014-2018 without the temporarily occupied territory of the Autonomous Republic of Crimea, the city of Sevastopol and part of the temporarily occupied territories in Donetsk and Luhansk regions.
} 


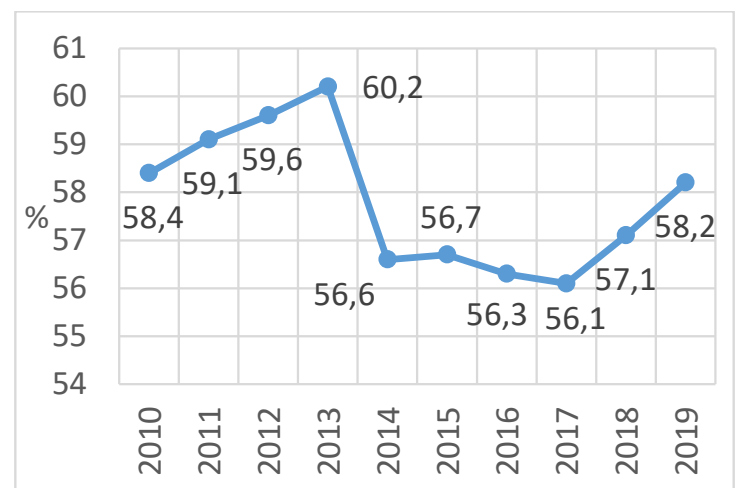

Figure 5. Employed population aged 15-70 years in \% of the population of the corre-sponding age group

Source: (Derzhavna sluzhba statystyky Ukrainy, 2021) ${ }^{4}$

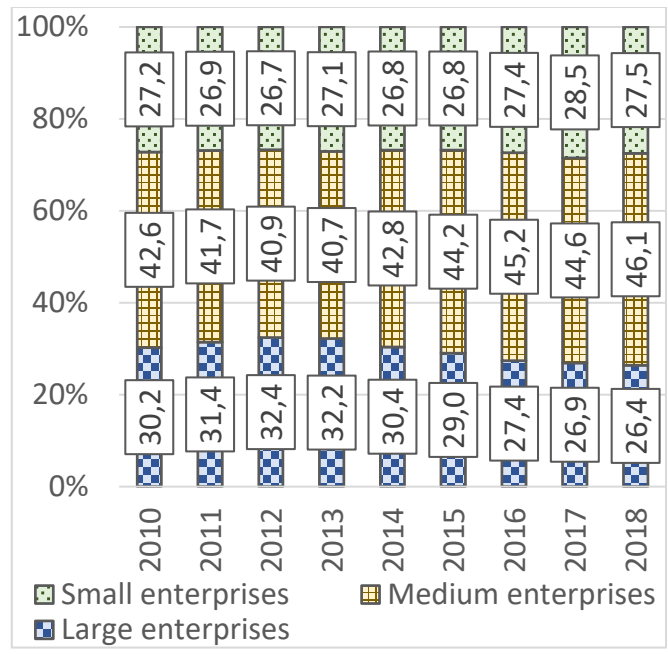

Figure 7. The structure of employment by size of enterprises

Source: (Derzhavna sluzhba statystyky Ukrainy, 2021) ${ }^{6}$

\section{Financial results of enterprises}

Figure 9 clearly confirms the existence of the economic crisis in 2014 and 2015. Each segment of enterprises by size in monetary terms shows a total loss in these years. However, the indicator of the share of profitable enterprises in the number of objects of the corresponding size shows a less unequivocal situation. We see that from 2013 to 2014 in the segment of large enterprises there is a significant de-cline in the share of profitable enterprises (from 68\% to 49\%). At the same time, in the segment of small enterprises in the same period we see an increase in the number

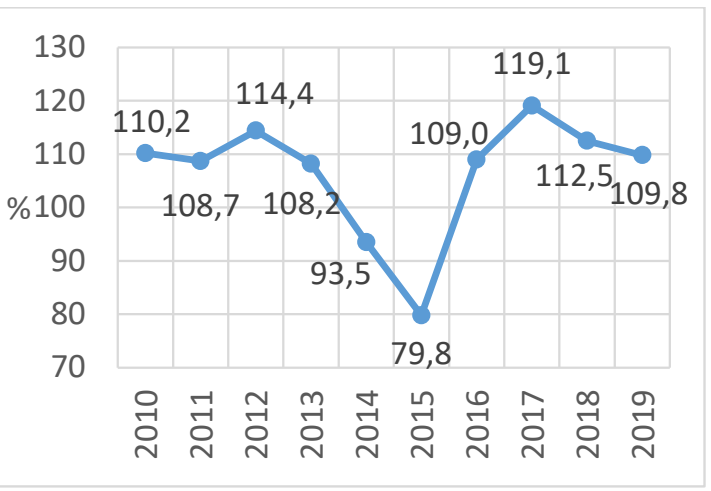

Figure 6. Dynamics of real average monthly wages in $\%$ to the previous year

Source: (Derzhavna sluzhba statystyky Ukrainy, 2021)

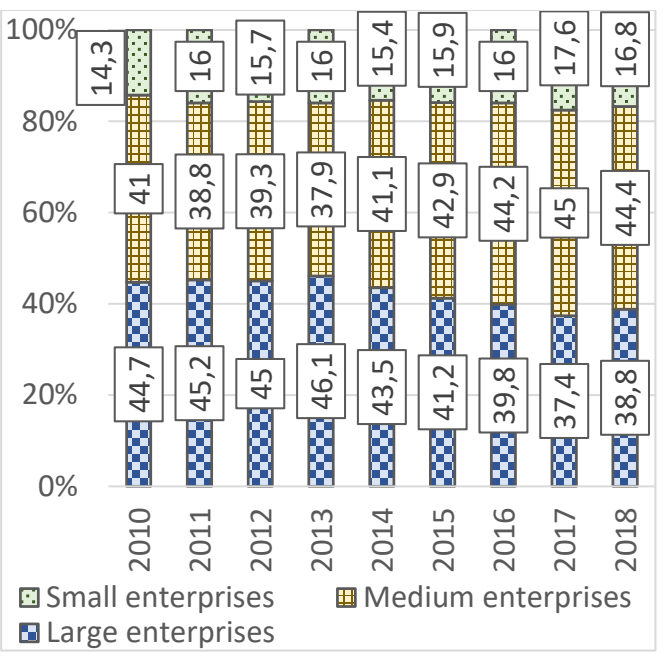

Figure 8. Structure of labor costs by size of enterprises in \% of the total

Source: (Derzhavna sluzhba statystyky Ukrainy, 2021) ${ }^{7}$

of profitable entities and in 2015 it reached $73 \%$. In addition, we see that in 2015 the share of mediumsized enterprises that made a profit also increased significantly (up to $71 \%$ ). Thus, given the importance of the indicators shown in the previous graphs, we can conclude that the crisis of 2014-2015 caused the greatest losses to large enterprises. At the same time, the position of small and medium enterprises has strengthened. In 2016, we observe the normalization of the situation, in total, large and medium-sized enterprises show a profit, small enterprises, as in the pre-crisis period - a loss. Already in 2018, all

\footnotetext{
${ }^{4}$ Data for 2010-2014 are given without taking into account the temporarily occupied territory of the Autonomous Republic of Crimea and the city of Sevastopol, since 2015 - also without part of the temporarily occupied territories in Donetsk and Luhansk regions.

${ }^{5}$ Data are given for legal entities and separate divisions of legal entities with the number of employees of 10 or more persons.

${ }^{6}$ The data are given without taking into account the results of banks and budgetary institutions, for 2014-2018 without taking into account the temporarily occupied territory of the Autonomous Republic of Crimea, Sevastopol and part of the occupied territories in Donetsk and Luhansk regions.

${ }^{7}$ The data are given without taking into account the results of banks and budgetary institutions, for 2014-2018 without taking into account the temporarily occupied territory of the Autonomous Republic of Crimea, Sevastopol and part of the temporarily occupied territories in Donetsk and Luhansk regions.
} 


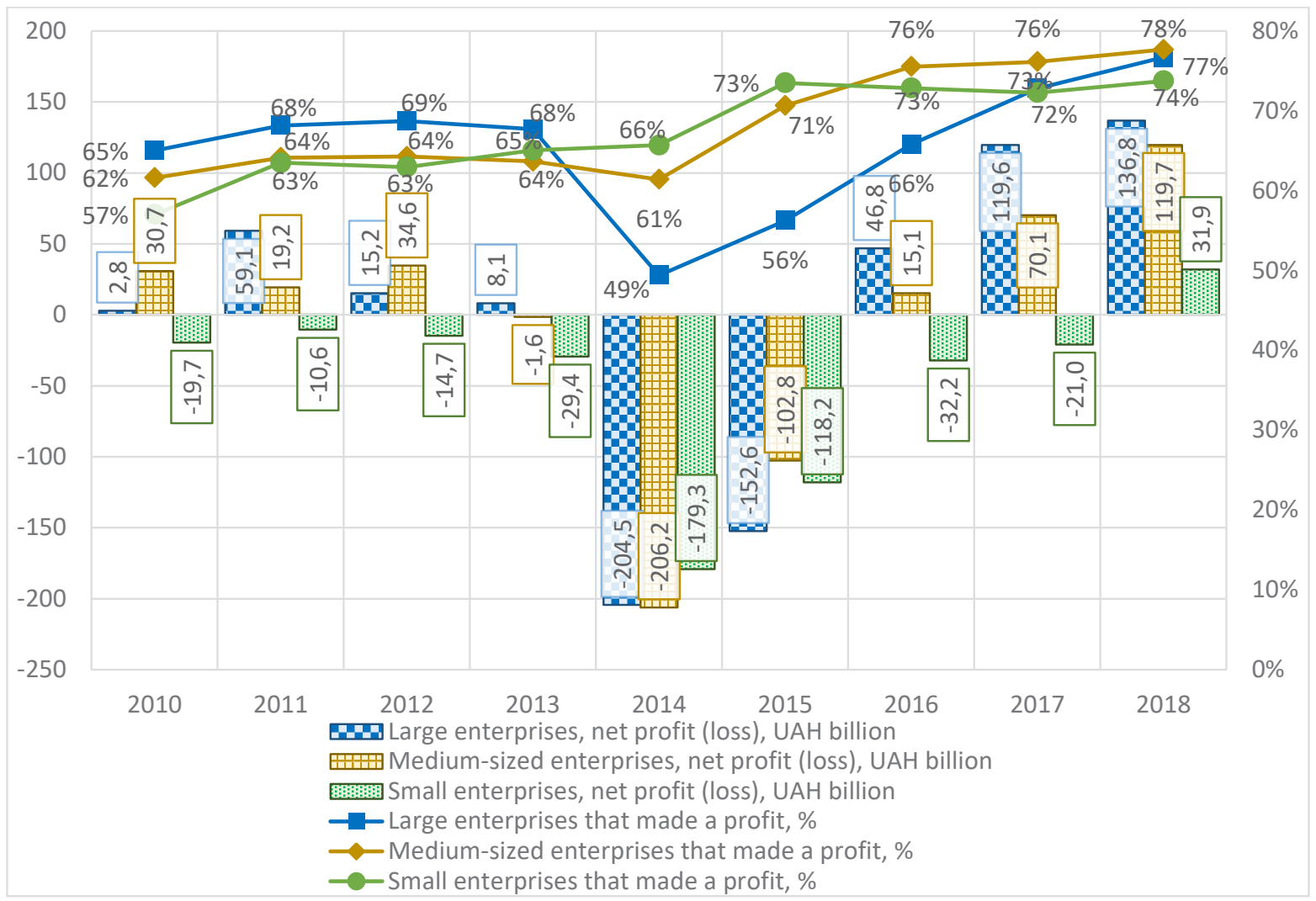

Figure 9. Net profit (loss) of enterprises and the share of enterprises that received profit by companies size

Source: (Derzhavna sluzhba statystyky Ukrainy, 2021) ${ }^{8}$

segments of companies by size show a profit in total. Comparing the periods before 2013 and after 2016, we should note an increase in the share of profitable enterprises in each segment. Before 2013, about 62\% of all medium-sized enterprises were profitable, after $2016-73 \%$. Respectively for medium-sized $-63.5 \%$ against $76.4 \%$. Regarding large enterprises, we see a steady trend of increasing the share of profitable enterprises, which in 2018 exceeded the average of the pre-crisis period and amounted to $77 \%$. Based on this, we must recognize the differences between the state of the economy before and after the crisis. Of course, such differences are important in modeling financial sustainability, because a randomly selected pre-crisis enterprise is less likely to be profitable than a post-crisis enterprise selected in the same way. This means that a model that uses only indicators of the company's internal state and its training was based on pre-crisis data will lose its accuracy when used in post-crisis observations, as there are changes in the economic environment.

Figure 10 and Figure 11 show the decline in profitability of enterprises operating activities of all sizes. In 2014, we see a total loss of $-4.1 \%$, which indicates the existence of the economic crisis. In 2015, the overall operating profitability is already positive and equal to $1.0 \%$, but is still at a level much lower than the pre-crisis period. At the same time, we note that according to the value of this indicator, small enterprises are affected, $-17.9 \%$ in 2014 . Also, large enterprises generally maintained a positive level of operating profitability. We see that since 2016 the situation has stabilized, and the new trend in the level of profitability is higher than the pre-crisis period, both for the overall indicator and for each individual segment by size of enterprises.

\section{Domestic consumption}

Assessing changes in the market for manufactured products, let us look at Fig-ure 12. There is a clear change in the trend of the share of goods produced in Ukraine. We see that by 2014 the share of Ukrainian goods in the Ukrainian market fell sharply at about the same rate. Since 2014, it continues to decline, but the pace is slowing down significantly. And in 2019 there is already growth. In our opinion, the change in the described trend is a manifestation of changes in the economic environment in 2014-2015.

\footnotetext{
${ }^{8}$ Excluding the results of banks. For 2014-2018 without taking into account the temporarily occupied territory of the Autonomous Republic of Crimea, the city of Sevastopol and part of the temporarily occupied territories in Donetsk and Luhansk regions.
} 


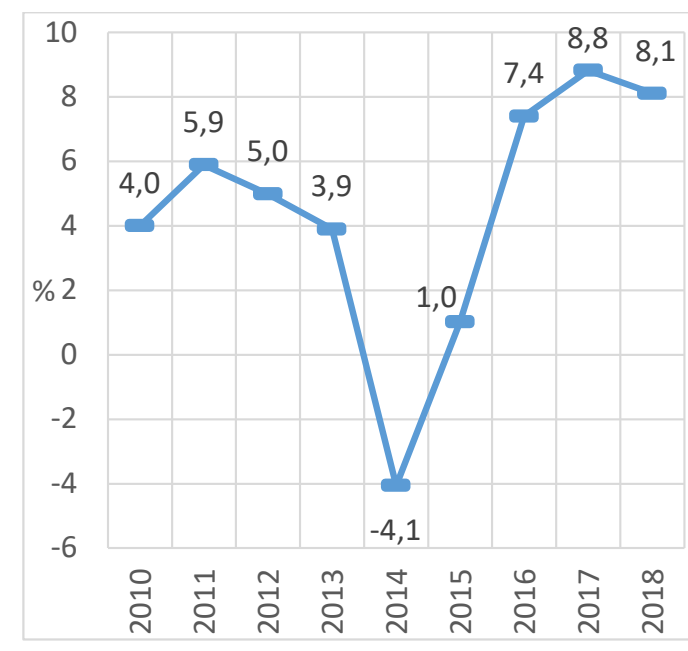

Figure 10. The level of profitability (loss) of enterprises operating activity, \%

Source: (Derzhavna sluzhba statystyky Ukrainy, 2021) 9

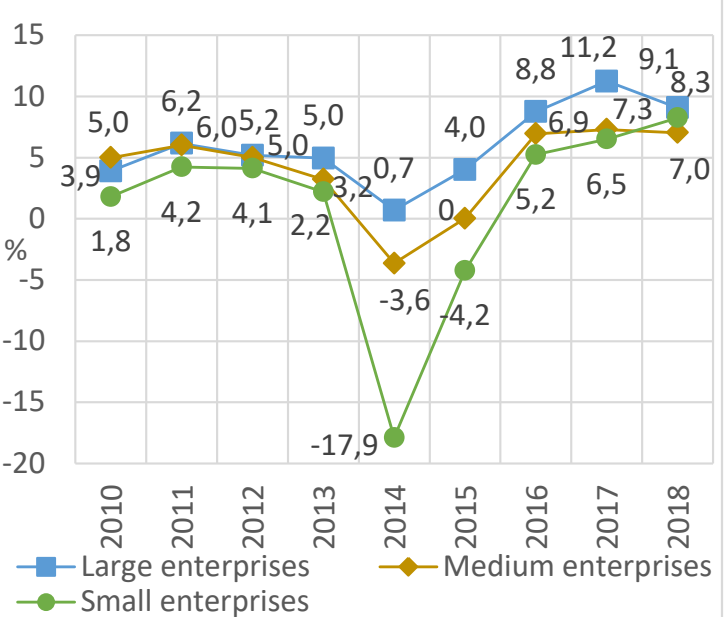

Figure 11. The level of profitability (loss) of op-erating activity by size of enterprises, \%

Source: (Derzhavna sluzhba statystyky Ukrainy, 2021)10
Another confirmation of the existence of crisis phenomena in the period 2014-2015 is the value of the Consumer Price Index in these years (Figure 13). The highest growth rate of prices was observed in 2015, which amounted to $48.7 \%$ of the 2014 price level. We note the decline in the value of the index in 2016 and its further stabilization, which can be perceived as the end of the deep phase of the economic crisis.

\section{Foreign trade}

In Figure 14 and Figure 15 concerning the crisis period of 2014-2015, we see a de-cline in the amount of exported goods and services in all geographical areas. Exports to the CIS (Commonwealth of Independent States) decreased the most for both goods and services. In this area, exports of goods decreased from 22.1 billion USD in 2013 to 6 billion USD in 2016. Exports of services - from 5.8 to 3.7 billion USD, respectively. The graphs show that in the post-crisis period (since 2016) the volume of exports in all other areas begins to grow monotonously, while the volume of exports to the CIS countries remains at the level of the crisis period. We also note a rapid increase in sales of Ukrainian goods and services to the European countries. We see that in 2018 the value of exports exceeded the level of pre-crisis years and reached 20.6 billion USD. It should be noted that before the events of 20142015 , the CIS countries occupied a leading position in Ukraine's exports of both goods and services. However, after the crisis in the geographical structure of Ukraine's exports, this area ranks 3rd in terms of trade in goods (after Europe and Asia) and 2nd in trade in services (after Europe). We also see that Europe is confidently becoming the main exports destination for Ukraine in the post-crisis period.

Figure 16 and Figure 17 show the changes in the volume of imports of goods and services to Ukraine by geographical areas. We see that the values of goods import in almost all areas reach the lowest level in 2015 (the direction of the CIS countries in 2016). We also see a clear decline in imports from the CIS countries. In contrast to the pre-crisis period, in 2016 and 2017 the amount of imports of services from the CIS countries is lower than the amount of imports from the Americas. We also note the rapid growth of this indicator for goods and services in the direction of Europe.

Thus, changes in the geographical structure of Ukraine's foreign trade are ob-vious. As you can see, until 2013, Ukraine's main trading partner was a group of CIS countries. After 2016, the most active trade is with European countries. The change in the course of foreign trade is largely politically motivated. After the Russian Federation carried out acts of aggression against Ukraine (occupation of the Crimean peninsula and support for terrorist organizations in Donetsk and Luhansk regions), starting in March 2014, Ukraine began to apply sanctions against a number of individuals and legal entities in Russia (Ukaz Prezydenta Ukrainy No.549/2015, 2015; Ukaz Prezydenta Ukrainy No.550/2015, 2015). On the other hand, on June 27, 2014, the economic part of the Association Agreement between Ukraine and the European Union was signed, which in particular concerns the establishment of a common free trade area, economic and financial cooperation (Verkhovna Rada Ukrainy, 2014).

\footnotetext{
${ }^{9}$ Excluding the results of banks. For 2014-2018 without taking into account the temporarily occupied territory of the Autonomous Republic of Crimea, the city of Sevastopol and part of the temporarily occupied territories in Donetsk and Luhansk regions.

${ }^{10}$ Excluding the results of banks. For 2014-2018 without taking into account the temporarily occupied territory of the Autonomous Republic of Crimea, the city of Sevastopol and part of the temporarily occupied territories in Donetsk and Luhansk regions.
} 


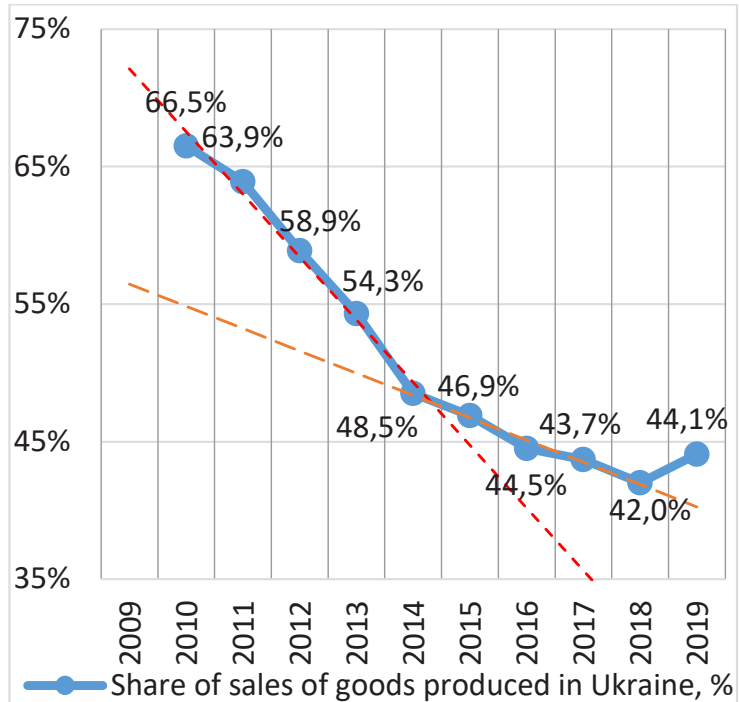

Figure 12. Share of goods produced in Ukraine sales, among the total turnover of wholesale enterprises

Source: (Derzhavna sluzhba statystyky Ukrainy, 2021) ${ }^{11}$

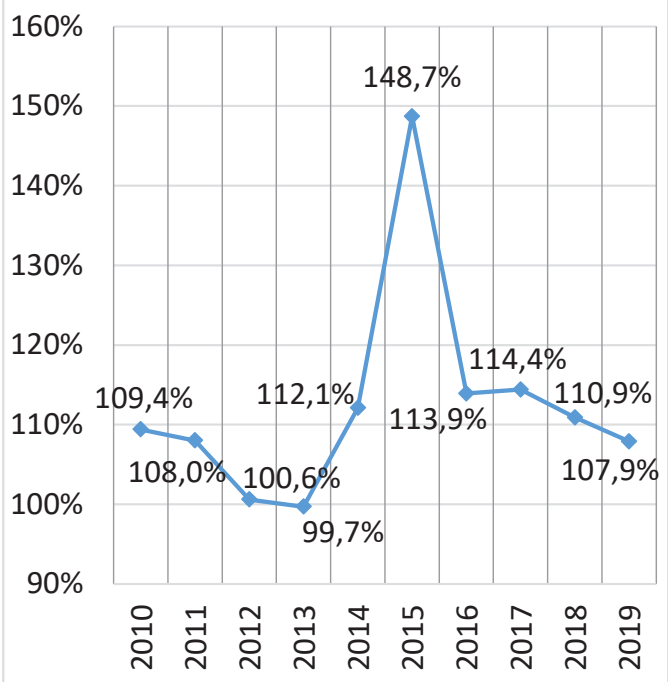

Figure 13. Consumer Price Index for goods and services (up to the previous year; percent)

Source: (Derzhavna sluzhba statystyky Ukrainy, 2021) 12

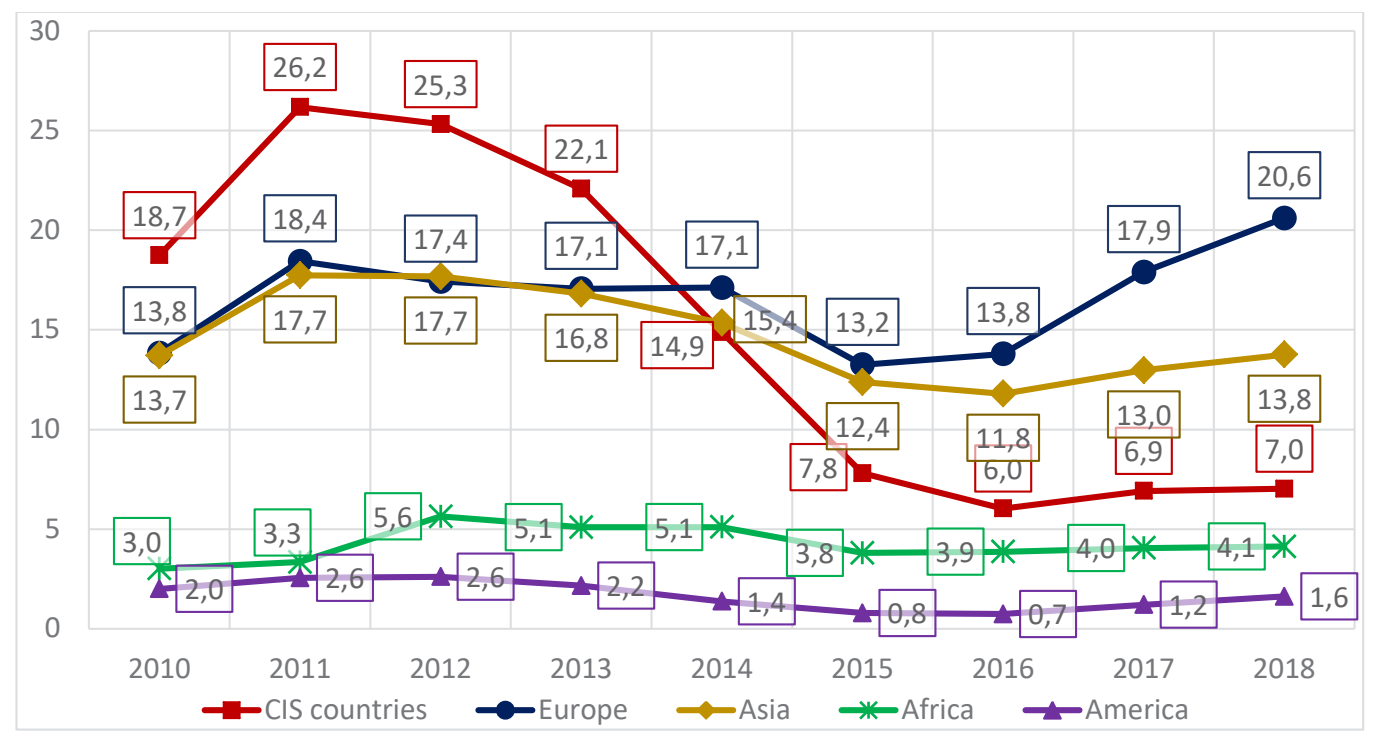

Figure 14. Dynamics of the goods exports geographical structure, billion USD

Source: (Derzhavna sluzhba statystyky Ukrainy, 2021) ${ }^{13}$

The process of changing the geographical structure of foreign trade has a sig-nificant impact on the financial sustainability of enterprises. Closing the possibility of presence in the old markets and opening new ones requires active action to reconfigure the usual ways of doing business. In particular, enterprises face such tasks as adaptation to new sales conditions, change of pricing policy, registration of documents that will allow to sell products in these markets, changes in activities related to legal differences in markets, bringing product quality to new standards, search and establishment of connections with new contractors, etc. At the same time, the ban on imports of raw materials and services from conventional

\footnotetext{
${ }^{11}$ Data for the period 2014-2019 are given without taking into account the temporarily occupied territory of the Autonomous Republic of Crimea, the city of Sevastopol and part of the temporarily occupied territories in Donetsk and Luhansk oblasts.

${ }^{12}$ Since 2014, the data are given without taking into account the temporarily occupied territory of the Autonomous Republic of Crimea and the city of Sevastopol. Since 2015, the data are given without taking into account part of the temporarily occupied territories in Donetsk and Luhansk regions.

${ }^{13}$ Since 2014, excluding the temporarily occupied territory of the Autonomous Republic of Crimea, the city of Sevastopol and part of the temporarily occupied territories in Donetsk and Luhansk regions.
} 


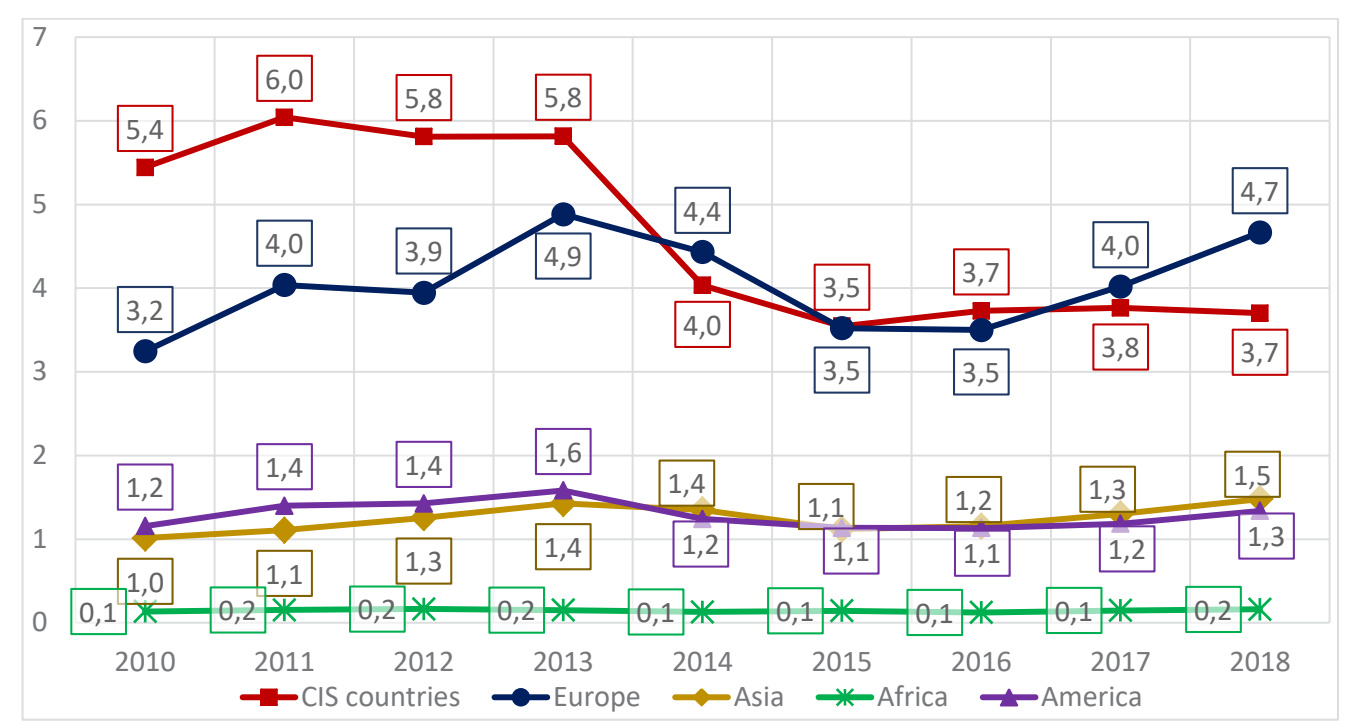

Figure 15. Dynamics of the services exports geographical structure, billion USD

Source: (Derzhavna sluzhba statystyky Ukrainy, 2021) ${ }^{14}$

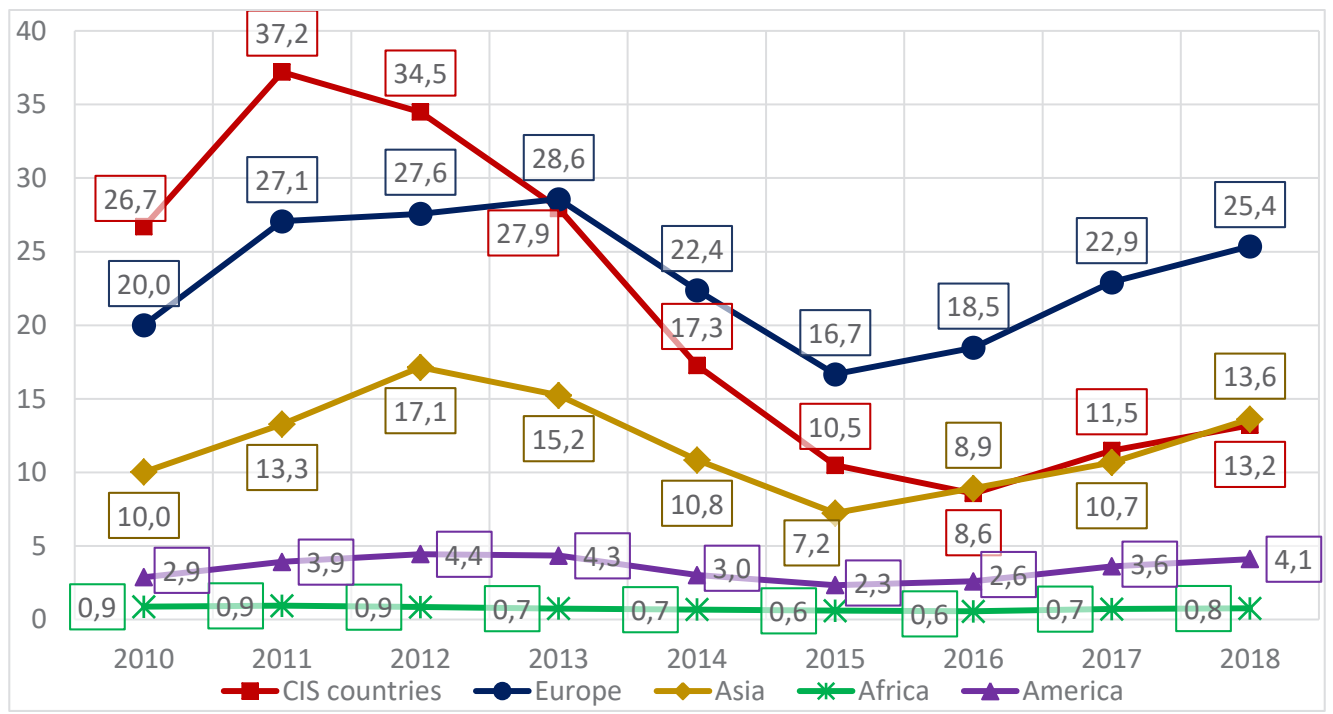

Figure 16. Dynamics of the goods imports geographical structure, billion USD

Source: (Derzhavna sluzhba statystyky Ukrainy, 2021) ${ }^{15}$

sources also affects the company, leads to changes in costs, readjustment of production technologies to the quality of new raw materials, search for new suppliers, change the amount of transportation costs, etc. It is obvious that a sharp change in the geographical direction of cooperation plunges the company into a state of stress, in the period of adaptation to new conditions, the forecasts of the financial future of the company are quite uncertain. In addition, after the reorientation of the company to a new market and adaptation of production to new sources of raw materials, it is logical to assume that the structure of costs and profitability of the company changes compared to previous periods. Thus, when such a phenomenon occurs en masse, it should be borne in mind that after the foreign economic reorientation of the country, the actual averages of many financial indicators will change, and therefore their real values,

${ }^{14}$ Information for 2010-2013 is given without taking into account the temporarily occupied territory of the Autonomous Republic of Crimea and the city of Sevastopol, for 2014-2016 - without taking into account the temporarily occupied territory of the Autonomous Republic of Crimea, the city of Sevastopol and part of the anti-terrorist operation zone, for 2017-2019 - without taking into account temporarily occupied territory of the Autonomous Republic of Crimea, the city of Sevastopol and parts of the temporarily occupied territories in Donetsk and Luhansk regions.

${ }^{15}$ Since 2014, excluding the temporarily occupied territory of the Autonomous Republic of Crimea, the city of Sevastopol and part of the temporarily occupied territories in Donetsk and Luhansk regions. 


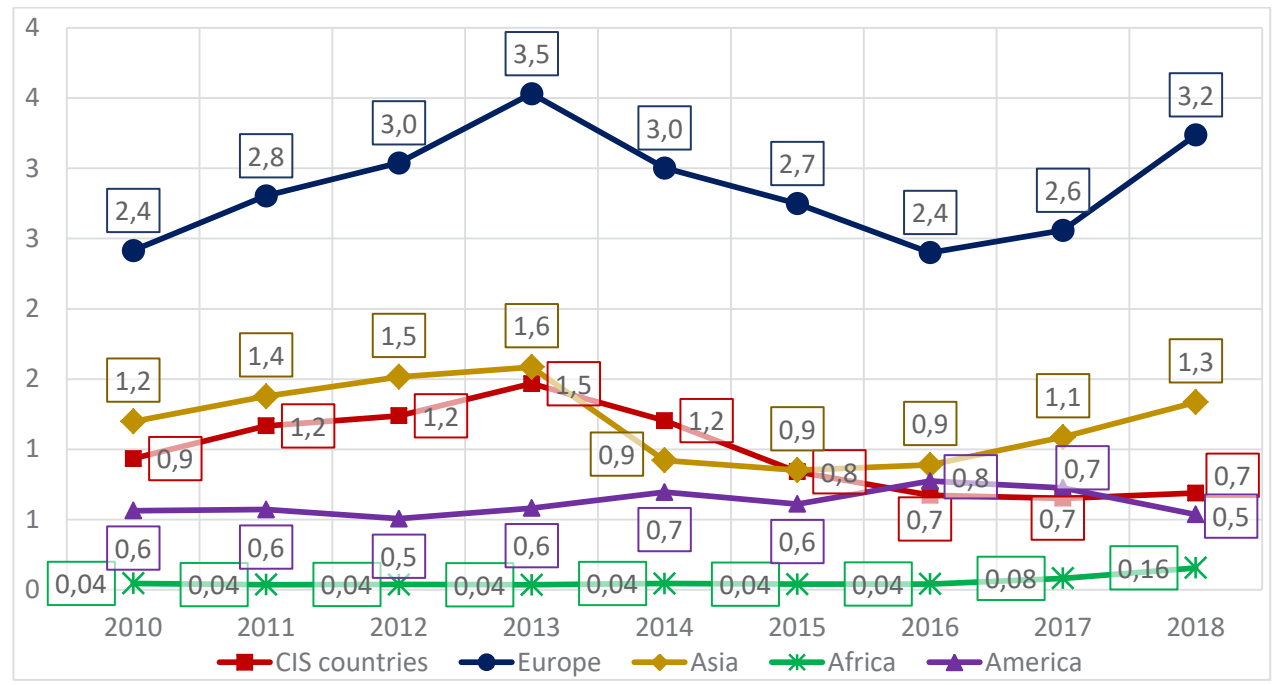

Figure 17. Dynamics of the services imports geographical structure, billion USD

Source: (Derzhavna sluzhba statystyky Ukrainy, 2021) ${ }^{16}$

which ensure financial sustainability, may also differ from previous periods. In other words, a change in the direction of foreign trade can lead to a change in the levels of normal values of financial indicators, which maintain the financial sustainability of companies.

\section{Innovations}

Figure 18 shows the lowest number of implementations of new production technologies in 2015 , and the highest - in 2016. In our opinion, this indicates a readjustment of production due to changes in the economic environment in 2014-2015. The introduction of new technologies requires preparing and investment, which takes some time. We can assume that in 2014, when economic changes began, enterprises in general completed the introduction of technologies prepared in previous years and canceled the introduction of technologies that were associated with the lost relevance of trade and economic conditions, in particular with cooperation with

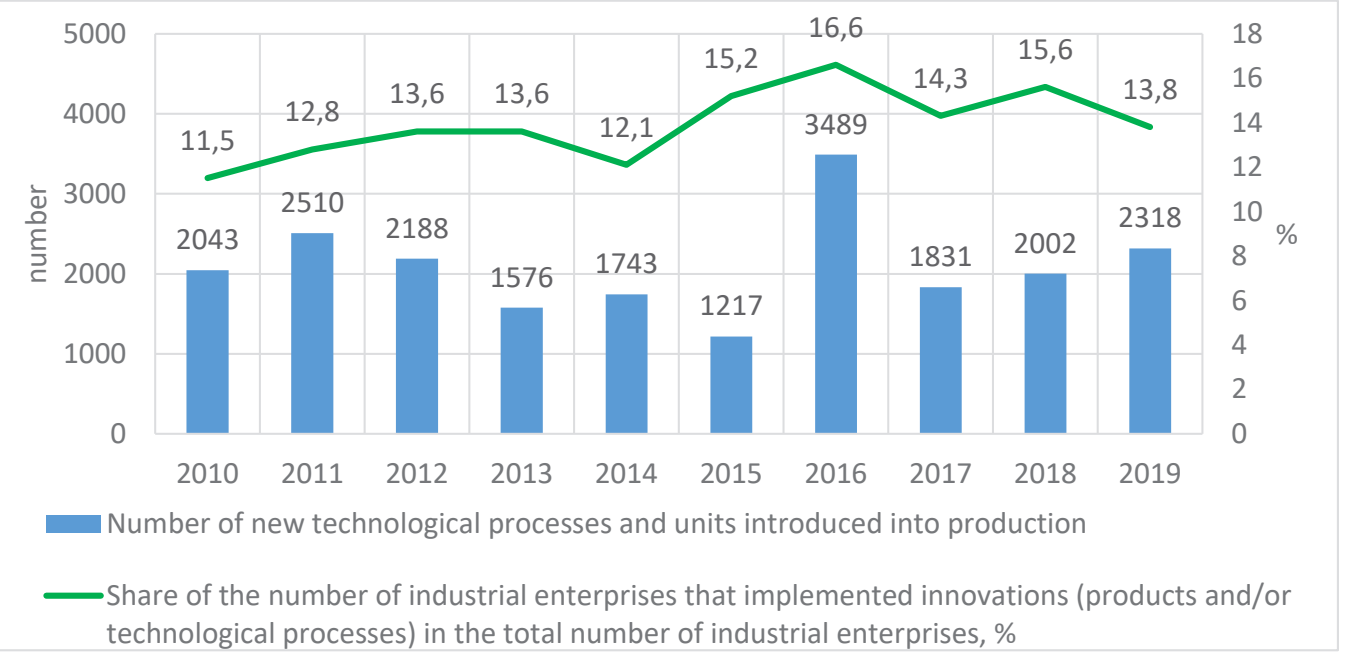

Figure 18. Introduction into production of new technological processes and products at in-dustrial enterprises Source: (Derzhavna sluzhba statystyky Ukrainy, 2021) ${ }^{17}$

\footnotetext{
${ }^{16}$ Information for 2010-2013 is given without taking into account the temporarily occupied territory of the Autonomous Republic of Crimea and Sevastopol, for 2014-2016 - without taking into account the temporarily occupied territory of the Autonomous Republic of Crimea, Sevastopol and part of the anti-terrorist operation zone, for 2017-2019 - without temporarily occupied territory of the Autonomous Republic of Crimea, the city of Sevastopol and parts of the temporarily occupied territories in Donetsk and Luhansk regions.

${ }^{17}$ Data for 2010-2014 are given for legal entities and their separate divisions that carried out industrial activities. Data for 2014-2019 are given without taking into account the temporarily occupied territory of the Autonomous Republic of Crimea, the city of Sevastopol and parts of the temporarily occupied territories in Donetsk and Luhansk oblasts. Data for 2015-2019 are given for legal entities engaged in industrial activities, with an average number of employees of 50 people and more.
} 
CIS countries (which explains the low number of implementations in 2015). Following this reasoning, we can assume that in 2015 the companies were engaged in the preparatory processes of technological change and began their implementation, and during 2016 we see a large number of completion of these projects.

\section{Conclusions}

Thus, analyzing the dynamics of a significant number of indicators of Ukraine's economy in the period 2010-2019, we can draw some conclusions. We must acknowledge the existence of the economic crisis that began in 2014. In support of this, the decline in the physical volume of GDP, the fall in the national currency, rising unemployment, high inflation, falling real average monthly wages, reducing the number of large and medium enterprises, recorded total losses for each of the segments by size of enterprises, negative level of profitability of operating activities, falling foreign economic activity (both exports and imports of goods and services). As a result of the analysis, it was found that crisis phenomena are observed during
2014 and 2015. The values of indicators in 2016 remain a fairly stable trend in the coming years, i.e. this period can be considered non-crisis. The levels of indicators of the pre-crisis period differ from the levels of the post-crisis period. We can observe the indicators of the national currency exchange rate, the structure of employment and the structure of labor costs by size of enterprises, the distribution of total sales by size of enterprises, shares of profitable enterprises and levels of operating profitability by size of enterprises, changes in sales goods produced on the territory of Ukraine, a radical change in the structure of foreign trade in geographical areas.

Given the above, we reach the following conclusions. In order to build an adequate and relevant model of financial sustainability, it is unacceptable to use the reports of enterprises from the crisis periods of 2014-2015. The use of pre-crisis reports until 2013 may lead to an outdated model, which may demonstrate the low accuracy of estimates of new observations. Data from the period beginning in 2016 are the most suitable for building a model of financial sustainability of enterprises.

\section{References:}

Debunov, L. M., \& Yakovenko, A. G. (2019). Analiz sychasnykh pidkhodiv do vyvchennia poniattia finansovoi stiikosti pidpryiemstva [Analysis of modern approaches to defining the concept of financial sustainability of enterprise]. Scientific notes of the National University Ostroh Academy, series Economics, no. 12(40), pp. 86-91. doi: 10.25264/2311-5149-2019-12(40)-86-91

Debunov, L. M., \& Yakovenko, A. G. (2019). Formuvannia datasetu ta vybir parametriv dlia pobudovy shtuchnoi neironnoi merezhi klasyfikatsii pidpryiemstv za finansovoiu stiikistiu [Formation of the dataset and selection of parameters for the building of the artificial neural networks of the enterprises financial sustainability classification]. Review of transport economics and management, no. 17, pp. 158-169. doi: 10.15802/rtemt.v0i1(17).176655

Debunov, L. (2019). Modeling company's financial sustainability with the use of artificial neural networks. Economy and Forecasting, no. 3, pp. 76-93. doi: 10.15407/econforecast2019.03.076

Derzhavna sluzhba statystyky Ukrainy (2021). Statystychna informatsiia [Statistical information]. Kyiv: Informatsiino-analitychne ahentstvo. Available at: http://www.ukrstat.gov.ua

Natsionalnyi bank Ukrainy (2021). Ofitsiinyi kurs hryvni shchodo inozemnykh valiut [Official hryvnia exchange rate against foreign currencies]. Available at: https://bank.gov.ua/ua/markets/exchangerates?date=31.01.2021\& period=daily

Ukaz Prezydenta Ukrainy No. 549/2015 (2015). Pro rishennia Rady natsionalnoi bezpeky i oborony Ukrainy vid 2 veresnia 2015 roku "Pro zastosuvannia personalnykh spetsialnykh ekonomichnykh ta inshykh obmezhuvalnykh zakhodiv (sanktsii)" [On the decision of the National Security and Defense Council of Ukraine of September 2, 2015 "On the application of personal special economic and other restrictive measures (sanctions)"]. Available at: https://www.president.gov.ua/documents/5492015-19437

Ukaz Prezydenta Ukrainy No. 550/2015 (2015). Pro rishennia Rady natsionalnoi bezpeky i oborony Ukrainy vid 17 veresnia 2015 roku "Pro vnesennia zmin do dodatka 1 do rishennia Rady natsionalnoi bezpeky i oborony Ukrainy vid 2 veresnia 2015 roku "Pro zastosuvannia personalnykh spetsialnykh ekonomichnykh ta inshykh obmezhuvalnykh zakhodiv (sanktsii)" [On the decision of the National Security and Defense Council of Ukraine of September 17, 2015 "On amendments to Annex 1 to the decision of the National Security and Defense Council of Ukraine of September 2, 2015 " On the application of personal special economic and other restrictive measures (sanctions) "]. Available at: https://www.president.gov.ua/documents/5502015-19438

Verkhovna Rada Ukrainy (2014). Uhoda pro asotsiatsiiu mizh Ukrainoiu, z odniiei storony, ta Yevropeiskym Soiuzom, Yevropeiskym spivtovarystvom $z$ atomnoi enerhii $i$ yikhnimy derzhavamy-chlenamy, $z$ inshoji storony [Association Agreement between the European Union and the European Atomic Energy Community and their member states, of the one part, and Ukraine, of the other part]. Available at: https://zakon.rada.gov.ua/laws/show/984_011\#Text 